\title{
Job strain and cardiovascular risk factors: a cross sectional study of employed Danish men and women
}

\author{
Bo Netterstrøm, Tage Søndergård Kristensen, Mogens Trab Damsgaard, Ole Olsen, \\ Anette Sjøl
}

\begin{abstract}
As part of the World Health Organisation initiated MONICA project, 2000 men and women aged $30,40,50$, and 60 from the general population were invited to undergo a medical examination with special emphasis on cardiovascular disease. A total of 1504 (75\%) participated, 1209 of whom were employed. The participants answered a questionnaire on working, social, and health conditions and underwent clinical examinations that included the measurement of blood pressure and serum cholesterol, triglyceride, high density lipoprotein, fibrinogen, and glycated haemoglobin $\left(H_{b A_{1}} C\right)$ concentrations. Using the demandcontrol model for measuring job strain suggested by Karasek, the employed people were classified according to those who had suffered job strain and those who had not in two different ways. The subjective classification was based on the participants' statements regarding demand and control in their jobs whereas the objective classification was based on job title and mode of payment. More women than men were classified as having high strain jobs. After adjusting for age and sex no significant association was found between coronary risk factors and subjective job strain. A tendency for an association between fibrinogen and job strain was found. Body mass index and $\mathrm{HbA}_{1} \mathrm{C}$ concentration were significantly associated with objective job strain independent of confounders.
\end{abstract}

Clinic of Occupational Medicine, University Hospital, Copenhagen, Tagensvej 20, 2200 Copenhagen N, Denmark

B Netterstrøm

Institute of Social Medicine, University of Copenhagen, Denmark

T S Kristensen, M T Damsgaard, O Olsen

The Glostrup Population Studies, Department of Internal Medicine C, Glostrup Hospital, University of Copenhagen, Denmark

A Sjøl
Since Karasek ${ }^{1}$ launched his demand-control model as a tool to measure work related stress, or job strain, several studies have established a positive relation between job strain and ischaemic heart disease (IHD).$^{2-20}$ Although most of these studies have been cross sectional, case-referent studies ${ }^{2-4} 1920$ and follow up studies ${ }^{57816-18}$ have also been performed. In these studies job classification was based on two different methods. In the first method the participants are asked directly about job demands and decision latitude in their jobs and then each subject is classified by the job strain model according to his or her own responses (the so called "subjective" method). ${ }^{6910121319}$ The second method (the so called "objective" method) classifies the number of jobs on the basis of a large population survey. After the jobs are defined in relation to the job strain model, all the incumbents of a particular job are classified accordingly, regardless of the incumbent's perception of job strain. ${ }^{2-5}$ 14-17

Only a few studies have shed light on which pathophysiological mechanisms account for the consistent relation that has been established between IHD and job strain (defined as a combination of a low degree of job decision latitude and high demands). Of these studies ${ }^{217^{19-21}}$ only one $\mathrm{e}^{19}$ was in fact designed to elucidate this issue.

Subsequently, as part of the World Health Organisation-initiated MONICA project, we studied the relation between coronary risk factors and job strain, assessed on the basis of Karasek's model using both the subjective and objective methods. As well as the classic coronary risk factors, we found it relevant to incorporate biological measurements that in other contexts have proved to be associated with IHD and work related stress-namely, s-fibrinogen ${ }^{21-24}$ and blood glycated haemoglobin $\left(\mathrm{HbA}_{1} \mathrm{C}\right)$ concentrations. ${ }^{25-27}$ Studies have shown that s-fibrinogen concentration is an IHD risk factor and is, moreover, particularly associated with low social status. It has also been established that blood $\mathrm{HbA}_{1} \mathrm{C}$ concentration is associated with both subjectively perceived ${ }^{27}$ and objectively defined job strain. ${ }^{26}$ Ours was a cross sectional study of risk factors in a suburban population..$^{28}$ The study population will be followed up later with respect to the incidence of myocardial 
Table 1 Distribution of age and sex among the participants (percentage in parentheses)

\begin{tabular}{llllll}
\hline & \multicolumn{2}{l}{ Age $(y)$} & & \\
\cline { 2 - 5 } & 30 & 40 & 50 & 60 & Total \\
\hline Men & 174 & 193 & 187 & 194 & 748 \\
Women & $(12)$ & $(13)$ & $(12)$ & $(13)$ & $(50)$ \\
& $(12)$ & 195 & 191 & 188 & 756 \\
Total & 358 & 386 & 378 & 382 & 1504 \\
& $(24)$ & $(26)$ & $(25)$ & $(25)$ & $(100)$ \\
\hline
\end{tabular}

infarction (MI). Thus we will also be able to test Karasek's model in relation to the development of IHD.

\section{Materials and methods}

Two thousand men and women aged $30,40,50$, and 60 living in 11 municipalities in the southern part of Copenhagen County were invited to participate in the study. A total of 1504 accepted, corresponding to $75 \%$. Table 1 shows their distribution according to age and sex. The drop out was evenly distributed with respect to age and sex, as 250 people were invited for each age and sex group. Attached to the invitation was a standardised questionnaire asking for information on previous and current illnesses, symptoms, exercise habits, smoking habits, family medical history, use of medicine, working conditions, and family situation. Bringing the questionnaire with him or her, each participant, having fasted for some hours, came for a medical examination. The questionnaire was discussed with the participant. Their blood pressure, weight, and height were measured and a blood sample was taken. The following blood analyses were made: serum cholesterol, serum triglyceride, serum high density lipoprotein (HDL), serum fibrinogen, and blood $\mathrm{HbA}_{1} \mathrm{C}$ concentrations. Owing to limited resources, the last two were analysed only in men aged 50 and 60 .

As well as these variables we used questions from the questionnaire about smoking, information on antihypertensive treatment, information on symp-

Table 2 Age and sex distribution among employed participants (percentage in parentheses)

\begin{tabular}{|c|c|c|c|c|c|}
\hline & \multicolumn{4}{|c|}{ Age (y) } & \multirow[b]{2}{*}{ Tota } \\
\hline & 30 & 40 & 50 & 60 & \\
\hline $\begin{array}{l}\text { Men } \\
\text { Women }\end{array}$ & $\begin{array}{l}163 \\
(14) \\
158 \\
(13)\end{array}$ & $\begin{array}{l}188 \\
(16) \\
169 \\
(14)\end{array}$ & $\begin{array}{l}173 \\
(14) \\
151 \\
(13)\end{array}$ & $\begin{array}{c}140 \\
(11) \\
67 \\
(6)\end{array}$ & $\begin{array}{l}664 \\
(55) \\
545 \\
(45)\end{array}$ \\
\hline Total & $\begin{array}{l}321 \\
(27)\end{array}$ & $\begin{array}{l}357 \\
(30)\end{array}$ & $\begin{array}{l}324 \\
(27)\end{array}$ & $\begin{array}{l}207 \\
(17)\end{array}$ & $\begin{array}{l}1209 \\
(100)\end{array}$ \\
\hline
\end{tabular}

Table 3 Employment status among the participants

\begin{tabular}{|c|c|c|c|c|c|}
\hline & $\begin{array}{l}\text { No } \\
\text { of } \\
\text { men }\end{array}$ & $(\%)$ & $\begin{array}{l}\text { No } \\
\text { of } \\
\text { women }\end{array}$ & $(\%)$ & Total \\
\hline $\begin{array}{l}\text { Employer } \\
\text { Assistant employer } \\
\text { Skilled worker } \\
\text { Unskilled worker } \\
\text { White collar worker }{ }^{\star} \\
\text { White collar worker }{ }^{\dagger} \\
\text { Unemployed, retired etc }\end{array}$ & $\begin{array}{r}67 \\
0 \\
113 \\
120 \\
141 \\
223 \\
84\end{array}$ & $\begin{array}{l}(10) \\
(0) \\
(15) \\
(16) \\
(19) \\
(30) \\
(10)\end{array}$ & $\begin{array}{r}16 \\
15 \\
7 \\
107 \\
156 \\
244 \\
211\end{array}$ & $\begin{array}{l}(2) \\
(2) \\
(1) \\
(14) \\
(21) \\
(32) \\
(28)\end{array}$ & $\begin{array}{r}83 \\
15 \\
120 \\
227 \\
297 \\
467 \\
295\end{array}$ \\
\hline Total & 748 & $(100)$ & 756 & $(100)$ & 1504 \\
\hline
\end{tabular}

*Ten years or more in school.

tLess than 10 years in school.

toms of angina pectoris based on the Rose questionnaire,$^{30}$ and information on IHD in the family as dependent variables. We defined hypertension as systolic blood pressure of $160 \mathrm{~mm} \mathrm{Hg}$ or more, or diastolic blood pressure of $95 \mathrm{~mm} \mathrm{Hg}$ or more, or the participant's response of being under antihypertensive treatment. Hereditary predisposition for IHD was defined as a positive indication of the father, mother, or siblings having suffered acute $M I$.

Job strain, the independent variable, was measured in two ways. The subjective method was based on questions about decision latitude and work pace (see appendix). A low degree of decision latitude was defined as a total score of 3 or more when adding the individual points, as indicated in the appendix. High work pace was defined in the following manner; the work pace was much too high, or there was never time to do the job as well as one would have liked to, or work pace was slightly too high plus one was not able to do the job as well as one would have liked to. Job strain was then defined as the combination of a low degree of decision latitude and high work pace.

Also, a skill discretion variable was constructed using the two items on monotonous work and opportunities to learn new things. High skill discretion was defined as work considered varied combined with opportunities to learn new things.

Objective job strain was measured on the basis of the participant's job, occupation, work schedule, and mode of payment. The classification was carried out

Table 4 Mean values of coronary risk factors distributed according to employment status

\begin{tabular}{lccc}
\hline & Employed & Unemployed & p Value \\
\hline Cholesterol (mmol/1) & 6.0 & 6.6 & $<0.0001$ \\
Triglycerides (mmol/l) & 1.4 & 1.6 & $<0.01$ \\
HDL (mmol/1) & 1.4 & 1.5 & $<0.01$ \\
Fibrinogen (mmol/1) & 8.6 & 9.5 & 0.02 \\
HbA C $(\%)$ & 5.3 & 5.3 & NS \\
SBP $(\mathrm{mm} \mathrm{Hg})$ & 121.1 & 124.6 & $<0.01$ \\
DBP $(\mathrm{mm} \mathrm{Hg})$ & 75.1 & 76.1 & $\mathrm{NS}$ \\
BMI $\left(\mathrm{kg} / \mathrm{m}^{2}\right)$ & 24.9 & 24.6 & $\mathrm{NS}$ \\
\hline
\end{tabular}

SBP = Systolic blood pressure DBP = diastolic blood pressure. 
Table 5 Prevalence of risk factors according to employment status

\begin{tabular}{lccc}
\hline & $\begin{array}{c}\text { Employed } \\
(\%)\end{array}$ & $\begin{array}{l}\text { Unemployed } \\
(\%)\end{array}$ & $p$ Value \\
\hline Hypertension & $8 \cdot 7$ & $11 \cdot 1$ & $\mathrm{NS}$ \\
Smoking & 45 & 53 & 0.03 \\
Angina pectoris & 1.3 & $5 \cdot 0$ & $<0.01$ \\
Anamnestic former MI & 0.9 & 3.7 & $<0.01$ \\
Heredity & $20 \cdot 2$ & $22 \cdot 6$ & $\mathrm{NS}$ \\
\hline
\end{tabular}

in accordance with the method introduced by Karasek et al. ${ }^{12}$ Thus job strain occupations included factory worker, bus driver, seamstress, waitress, and assistant nurse.

At the time of the study 1209 of the participants were employed. Of these, 1081 answered all the questions on working conditions and only these were included in the analysis with respect to the relation betwen job strain and coronary risk factors. Table 2 shows the distribution by sex and age. Among the 295 who were not employed at the time of the study 123 had taken early retirement, 67 were housewives, 53 were unemployed, and the remainder were either students or unclassifiable. Table 3 shows the distribution according to sex.

For statistical analyses, we used Student's $t$ test for the continuous variables to evaluate the relation between job strain and coronary risk factors, and for the discrete variables we used the $\chi^{2}$ test. All the dependent variables were adjusted for sex and age by multivariate analysis (ANOVA SPSS). Finally, the relation between job strain and the risk factors was tested in multiple regression models in which weight, height, smoking, social network, and exercise habits were included in addition to sex and age. The significance level was set at $5 \%$.
Table 7 Prevalence of subjective job strain in different age and sex groups

\begin{tabular}{lrrrrr}
\hline & \multicolumn{2}{l}{ Age $(y)$} & \\
\cline { 2 - 5 } & 30 & 40 & 50 & 60 & Total \\
\hline $\begin{array}{lrrrr}\text { No of men } \\
\%\end{array}$ & 10 & 12 & 7 & 4 & 33 \\
$\begin{array}{l}\text { No of women } \\
\%\end{array}$ & 6 & 6 & 4 & 3 & 5 \\
Total & 13 & 17 & 24 & 7 & 69 \\
$\%$ & 31 & 29 & 16 & 10 & 13 \\
& 10 & 8 & 10 & 11 & 102 \\
\hline
\end{tabular}

\section{Results}

EMPLOYMENT STATUS

Table 4 shows the mean values of coronary risk factors for employed and unemployed people. The values for cholesterol, triglyceride, HDL, and fibrinogen concentrations were all clearly higher for the unemployed-this was also the case after adjusting for age and sex. The significant difference with regard to systolic blood pressure, however, disappeared when adjusting for age and sex. This is because among the unemployed relatively more participants were in the higher age groups.

The prevalences of the risk factors hypertension, smoking, hereditary predisposition, and symptoms of angina pectoris were greater among those who were not active in the labour market. After adjusting for sex and age, a significant difference only occurred for smoking and angina pectoris (table 5 ).

All the risk factors increased with age. Men had a significantly higher concentration of serum triglyceride and systolic and diastolic blood pressure. The difference in serum cholesterol concentration was not significant.

Table 6 Mean values and prevalence of coronary risk factors adjusted for age and sex according to skill discretion, decision latitude, and demand in the job

\begin{tabular}{|c|c|c|c|c|c|c|}
\hline & \multicolumn{2}{|c|}{ Skill discretion } & \multicolumn{2}{|c|}{ Decision latitude } & \multicolumn{2}{|l|}{ Demands } \\
\hline & $\begin{array}{l}\text { Low } \\
(n=415)\end{array}$ & $\begin{array}{l}\text { High } \\
(n=745)\end{array}$ & $\begin{array}{l}\text { Low } \\
(n=370)\end{array}$ & $\begin{array}{l}\text { High } \\
(n=757)\end{array}$ & $\begin{array}{l}\text { Low } \\
(n=828)\end{array}$ & $\begin{array}{l}\text { High } \\
(n=324)\end{array}$ \\
\hline $\begin{array}{l}\text { Cholesterol (mmol/l) } \\
\text { Triglycerides (mmol/1) } \\
\text { HDL (mmol/l) } \\
\text { Fibrinogen (mmol/l) } \\
\text { HbA C }(\%) \\
\text { SBP (mm Hg) } \\
\text { DBP (mm Hg) } \\
\text { BMI (kg/m²) } \\
\text { Hypertension (\%) } \\
\text { Smoking (\%) } \\
\text { Angina pectoris (\%) } \\
\text { Former MI (\%) } \\
\text { Heredity (\%) }\end{array}$ & $\begin{array}{r}6 \cdot 0 \\
1 \cdot 4 \\
1 \cdot 4 \\
8 \cdot 9 \\
5 \cdot 6 \\
123 \cdot 3 \\
76 \cdot 3 \\
24 \cdot 7 \\
8 \cdot 9 \\
53 \cdot 2 \\
1 \cdot 4 \\
1 \cdot 1 \\
20 \cdot 2\end{array}$ & $\begin{array}{r}6 \cdot 0 \\
1 \cdot 4 \\
1 \cdot 5 \\
8 \cdot 5 \\
5 \cdot 3 \\
120 \cdot 8 \\
75 \cdot 4 \\
25 \cdot 0 \\
8 \cdot 6 \\
49 \cdot 4 \\
1 \cdot 2 \\
1 \cdot 2 \\
21 \cdot 3\end{array}$ & $\begin{array}{r}6 \cdot 1 \\
1 \cdot 3 \\
1 \cdot 5 \\
8 \cdot 8 \\
5 \cdot 4 \\
121 \cdot 2 \\
75 \cdot 3 \\
24 \cdot 7 \\
11 \cdot 0 \\
54 \cdot 5 \\
1 \cdot 3 \\
0 \cdot 8 \\
19 \cdot 8\end{array}$ & $\begin{array}{r}6 \cdot 0 \\
1 \cdot 4 \\
1 \cdot 5 \\
8 \cdot 5 \\
5 \cdot 3 \\
121 \cdot 2 \\
75 \cdot 4 \\
25 \cdot 0 \\
7 \cdot 6 \\
48 \cdot 9 \\
1 \cdot 2 \\
1 \cdot 2 \\
20 \cdot 6\end{array}$ & $\begin{array}{r}6 \cdot 0 \\
1 \cdot 3 \\
1 \cdot 5 \\
8 \cdot 5 \\
5 \cdot 3 \\
121 \cdot 3 \\
75 \cdot 1 \\
24 \cdot 6 \\
9 \cdot 5 \\
48 \cdot 1 \\
1 \cdot 2 \\
0 \cdot 9 \\
20 \cdot 0\end{array}$ & $\begin{array}{r}6 \cdot 0 \\
1 \cdot 3 \\
1 \cdot 4 \\
8 \cdot 9 \\
5 \cdot 4 \\
122 \cdot 0 \\
75 \cdot 8 \\
25 \cdot 2 \\
8 \cdot 3 \\
54 \cdot 5 \\
1 \cdot 2 \\
1 \cdot 1 \\
20 \cdot 4\end{array}$ \\
\hline
\end{tabular}


Table 8 Prevalence of objective job strain in different age and sex groups

\begin{tabular}{lllllr}
\hline \multicolumn{3}{l}{ Age $(y)$} & & \\
\cline { 2 - 5 } & 30 & 40 & 50 & 60 & Total \\
\hline No of men & 28 & 33 & 23 & 15 & 99 \\
$\%$ & 17 & 18 & 13 & 11 & 15 \\
No of women & 36 & 31 & 62 & 22 & 151 \\
$\%$ & 23 & 18 & 41 & 33 & 28 \\
Total & 64 & 64 & 85 & 37 & 250 \\
$\%$ & 20 & 18 & 26 & 18 & 21 \\
\hline
\end{tabular}

SKILL DISCRETION, DECISION LATITUDE, AND DEMANDS Table 6 shows the levels of coronary risk factors according to skill discretion, decision latitude, and demands. The concentrations of fibrinogen and $\mathrm{HbA}_{1} \mathrm{C}$ and blood pressure, body mass index (BMI), and smoking seem to be higher in the groups with low skill discretion and decision latitude and high demands but the differences are not significant. None of the other risk factors showed any tendency to support the demand-control model.

The subjective classification of job strain showed that more women than men were in the job strain group. This applied to all age groups (table 7). Similarly, more women than men were placed in the job strain group when the objective classification was performed. As was the case in the subjective job strain classification, table 8 shows that particularly women aged 50 were placed in the job strain group.

The correspondence between the subjective and objective classifications was low, however (table 9). For $23 \%$ of the total participants no correspondence was found between the two methods of classification. Only 38 of the 1081 participants were placed in the job strain group when both the objective and the subjective methods were applied. The reason for this was that only $24 \%$ of those who were objectively classified as being in the job strain group had indicated high job demands in their response to the questionnaire. By contrast, $65 \%$ in the job strain group had indicated low decision latitude when answering the questionnaire.

JOB STRAIN

Tables 10 and 11 show the distribution of coronary

Table 9 The distribution of participants in job strain groups

\begin{tabular}{lcrrr}
\hline & \multicolumn{4}{c}{ Objective strain } \\
\cline { 3 - 5 } & & Yes & No & Total \\
\hline Subjective strain & Yes & 38 & 63 & 101 \\
Notal & No & 171 & 809 & 980 \\
& & 209 & 872 & 1081 \\
\hline
\end{tabular}

Table 10 Mean values of risk factors adjusted for age and sex in job strain groups and other participants

\begin{tabular}{|c|c|c|c|c|}
\hline & \multicolumn{2}{|c|}{ Subjective strain } & \multicolumn{2}{|c|}{ Objective strain } \\
\hline & $\begin{array}{l}\text { Yes } \\
(n=\end{array}$ & $\begin{array}{l}N o \\
(n=\end{array}$ & $\begin{array}{l}Y e s \\
(n=\end{array}$ & $\begin{array}{l}\text { No } \\
(n=872)\end{array}$ \\
\hline $\begin{array}{l}\text { Cholesterol (mmol/l) } \\
\text { Triglycerides (mmol/l) } \\
\text { HDL (mmol/l) } \\
\text { SBP (mm Hg) } \\
\text { DBP (mm Hg) } \\
\text { Fibrinogen (mmol/l) } \\
\text { HbA C }(\%) \\
\text { BMI }\left(\mathrm{kg} / \mathrm{m}^{2}\right)\end{array}$ & $\begin{array}{r}6 \cdot 0 \\
1 \cdot 4 \\
1 \cdot 5 \\
122 \cdot 8 \\
75 \cdot 2 \\
9 \cdot 9 \\
5 \cdot 4 \\
25 \cdot 2\end{array}$ & $\begin{array}{r}6 \cdot 0 \\
1 \cdot 4 \\
1 \cdot 5 \\
121 \cdot 1 \\
75 \cdot 6 \\
8 \cdot 6^{\star} \\
5 \cdot 3 \\
24 \cdot 8\end{array}$ & $\begin{array}{r}6 \cdot 1 \\
1 \cdot 4 \\
1 \cdot 5 \\
120 \cdot 8 \\
75 \cdot 1 \\
8 \cdot 5 \\
5 \cdot 7 \\
25 \cdot 3\end{array}$ & $\begin{array}{c}6 \cdot 0 \\
1 \cdot 3 \\
1 \cdot 5 \\
121 \cdot 4 \\
75 \cdot 5 \\
8 \cdot 7 \\
5 \cdot 2^{\star \star} \\
24 \cdot 6^{\star \star \star}\end{array}$ \\
\hline
\end{tabular}

risk factors in the job strain groups after adjustment for sex and age. When applying the subjective classification, we found a tendency towards a higher concentration of fibrinogen in the job strain group. No significant relation was found between subjective job strain and hypertension, smoking, angina pectoris, or hereditary predisposition. Some indication of a relation between the decision latitude variables and a high risk factor profile was found but not at a significant level. Tables 10 and 11 further show that the same risk factors do not have a significant relation with objective job strain either. Under the objective classification $\mathrm{BMI}$ and $\mathrm{HbA}_{1} \mathrm{C}$ concentration were significantly higher in the job strain group than among the other participants. That $\mathrm{HbA}_{1} \mathrm{C}$ concentration was significantly higher in the job strain group was not attributable to participants with especially high values of $\mathrm{HbA}_{1} \mathrm{C}$ in this group. The range for $\mathrm{HbA}_{1} \mathrm{C}$ concentration in the job strain group was $4 \cdot 0$ $8.0 \%$ and in the non-job strain group $3 \cdot 0-8 \cdot 5 \%$.

\section{MULTIVARIATE ANALYSES}

We tested the relation between objective and subjective job strain and all the coronary risk factors that were measured, through multiple regression models. Height, weight, sex, age, and smoking were included as confounders in the analyses. These analyses did

Table 11 Prevalence of smoking, hypertension, angina pectoris, and heredity adjusted for age and sex according to job strain

\begin{tabular}{|c|c|c|c|c|}
\hline & \multicolumn{2}{|c|}{ Subjective job strain } & \multicolumn{2}{|c|}{ Objective job strain } \\
\hline & $\begin{array}{l}\text { Yes } \\
l n=\end{array}$ & $\begin{array}{l}N o(\%) \\
(n=980)\end{array}$ & $\begin{array}{l}\text { Yes } \\
(n=\end{array}$ & $\begin{array}{l}\text { No }(\%) \\
(n=872)\end{array}$ \\
\hline \multirow{2}{*}{$\begin{array}{l}\text { Smoking } \\
\text { Hypertension } \\
\text { Questionnaire: } \\
\text { positive angina } \\
\text { pectoris } \\
\text { Heredity }\end{array}$} & $\begin{array}{l}47 \\
11 \cdot 8\end{array}$ & $\begin{array}{l}50 \\
8.5\end{array}$ & $\begin{array}{l}50 \\
7 \cdot 3\end{array}$ & $\begin{array}{l}47 \\
8 \cdot 6\end{array}$ \\
\hline & $\begin{array}{r}1 \cdot 7 \\
16 \cdot 4\end{array}$ & $\begin{array}{r}1 \cdot 2 \\
21 \cdot 2\end{array}$ & $\begin{array}{r}1 \cdot 8 \\
16 \cdot 8\end{array}$ & $\begin{array}{r}1 \cdot 2 \\
21 \cdot 7\end{array}$ \\
\hline
\end{tabular}


not provide any new information; $\mathrm{HbA}_{1} \mathrm{C}$ concentration was still significantly associated with objective job strain whereas none of the other factors were significantly associated either with objective or subjective job strain. Nor was more information supplied by a multiple regression analysis testing the relation between $\mathrm{HbA}_{1} \mathrm{C}$ concentration and $\mathrm{BMI}$ and smoking as we found no relation between $\mathrm{HbA}_{1} \mathrm{C}$ concentration and the measured parameters. Similarly, no relation was established between $\mathrm{HbA}_{1} \mathrm{C}$ concentration and the results of other blood analyses.

\section{Discussion}

It was not possible in our cross sectional study to establish a relation between job strain and the classic coronary risk factors. The fact that this was a cross sectional study in which only employed people were examined may, however, have influenced the results. As we have shown, the participants who were not active in the labour market had a higher coronary risk profile than those participants who were employed. This could be due to employment reducing the risk of having a high coronary risk profile. On the other hand it would seem more likely that the non-employed had left the labour market precisely because of sickness, for example IHD. Among the non-employed, 3.7\% indicated that they had previously suffered $\mathrm{MI}$ as opposed to $0.9 \%$ in the employed group.

The fact that few participants aged 60 were in the job strain group, especially through subjective classification, suggests a certain selection from jobs with job strain. The response rate of $75 \%$ may also have contributed to an underestimation of a possible relation as it is likely that the non-participants had a lower health status than the participants. Our study is therefore not without a certain selection bias. Also, some information bias may have occurred in the subjective job classification. For example, a number of nurses and teachers-jobs that are not normally characterised by low decision latitude and high demands - were placed in the subjectively classified job strain group. The demand variable, measuring only a limited aspect of demand especially contributed to this.

Thus our study did not support previous findings of a relation between job strain and systolic blood pressure $^{217}$ or the relation between job strain and fibrinogen found in other published studies. ${ }^{21} 22$ Further, our study did not corroborate the findings of Pieper et al ${ }^{17}$ correlating smoking with job strain.

As pointed out by Chapman and her colleagues in their prospective study on perceived work stress and blood pressure change ${ }^{31}$ the cross sectional design may be responsible for the lack of support to the hypothesis. The Australian baseline study had results like ours. ${ }^{32}$ Other longitudinal studies have indicated that variations in blood pressure correlate well with changes in job strain. ${ }^{33}$

The established relation between $\mathrm{HbA}_{1} \mathrm{C}$ concentration and objectively classified job strain may be the key to further understanding of the possible relation that other studies have found between IHD and job strain as defined by Karasek. ${ }^{1}$ Other studies have found an association between $\mathrm{HbA}_{1} \mathrm{C}$ concentration and, in particular, objectively classified job strain ${ }^{25-27}$ and it is likely that work related stress does in fact increase the risk of IHD through its catabolic effect on the metabolism, as suggested by Sterling and Eyer ${ }^{34}$ and Karasek et al. ${ }^{12} \mathrm{~A}$ catabolic change in metabolism will make the insulin concentration decrease and blood sugar increase, leading to an increased concentration of $\mathrm{HbA}_{1} \mathrm{C}$, which is an integrated measure of the concentration of blood sugar over the preceding weeks. ${ }^{35} \mathrm{~A}$ change of metabolism in this direction will lead to release of catecholamines and corticosteroids, which may accelerate the arteriosclerotic process. ${ }^{12}$

Results of measurements of hormones like catecholamines and corticosteroids in studies on chronic stress have been difficult to interpret, due to methodological difficulties in sample collection and dependence on food intake, diurnal variation, and physical exercise before sample collection. Blood $\mathrm{HbA}_{1} \mathrm{C}$ concentration might be a better marker of chronic stress, as none of these methodological problems are present when assessing this marker.

The validity of the above arguments may be tested in a prospective follow up of the study cohort with respect to IHD. This follow up study will take place in the 1990s as part of the MONICA project.

Our study was supported by the Danish Work Environment Fund (1985/28). We thank Ms MariAnne $\emptyset$ rum for typing the manuscript.

Requests for reprints to: Dr Bo Netterstrøm.

\section{Appendix}

QUESTIONS USED IN THE DECISION LATITUDE INDEX

$\begin{array}{lll} & \text { Answer } & \text { Points } \\ \text { Influence on work organisation } & \text { A great deal } & 0 \\ & \text { Little } & 1 \\ & \text { None } & 2 \\ \text { Work is varied or monotonous } & \text { Varied } & 0 \\ & \text { Neither } & 1 \\ & \text { Monotonous } 2\end{array}$

May do personal errands with- Yes out special permission No

No 1

Must make sure to be at work Yes, always 2 on time No 0 


\begin{tabular}{lll}
\multicolumn{2}{l}{ Can decide when to take a breakYes } & 0 \\
& No & 1 \\
Allowed private visits of & Yes & 0 \\
10 minutes & No & 1 \\
Opportunities to learn new & Yes & 0 \\
things & Few & 1 \\
& None & 2
\end{tabular}

Low decision latitude: sum greater than 2 points

\section{QUESTIONS USED IN THE DEMAND CONTEXT}

Answer

$\begin{array}{lll}\text { Work place } & \text { a } & \begin{array}{l}\text { Much too high } \\ \text { Somewhat too } \\ \text { high }\end{array} \\ & \text { c } & \text { Suitable/low } \\ \text { Time to do the job as well as } & \text { d } & \text { Yes } \\ \text { you would like to } & \text { e } & \text { Not usually } \\ & \text { f } & \text { Never }\end{array}$

High demands: $a$ or $f$ or $(b+e)$

1 Karasek RA. Job demands, job decision latitude and mental strain: implications for job redesign. Administrative Science Quarterly 1979;24:285-308.

2 Ahlbom A, Karasek R, Theorell T. Psykosociala arbetskrav och risk för hjärt-kärldöd. Läkartidningen 1980;77:4243-5.

3 Alfredsson L, Karasek R, Theorell T. Myocardial infarction risk and psychosocial work environment: an analysis of the male Swedish working force. Soc Sci Med 1982;16:463-7.

4 Alfredsson L, Theorell T. Job characteristics of occupations and myocardial infarction risk: effect of possible confounding factors. Soc Sci Med 1983;17:1497-503.

5 Alfredsson L, Spetz C-L, Theorell T. Type of occupation and near-future hospitalization for myocardial infarction and some other diagnoses. Int J Epidemiol 1985;14:378-88.

6 Braun S, Hollander R. A study of job stress among women and men in the Federal Republic of Germany. Health Education Research 1987;2:45-51.

7 Haan MN. Job strain and cardiovascular disease: a ten-year prospective study. Am J Epidemiol 1985;122:532.

8 Haan MN. Job strain and ischaemic heart disease: an epidemiologic study of metal workers. Ann Clin Res 1988; 20:143-5.

9 Johnson JV, Hall EM. Job strain, work place, social support and cardiovascular disease: A cross-sectional study of a random sample of the Swedish working population. Am J Public Health 1988;78:1336-42.

10 Johnson JV, Hall EM, Theorell T. Combined effects of job strain and social isolation on cardiovascular disease morbidity and mortality in a random sample of the Swedish male working population. Scand J Work Environ Health 1989;15:271-9.

11 Karasek R, Baker D, Marxer F, Ahlbom A, Theorell T. Job decision latitude, job demands and cardiovascular disease: a prospective study of Swedish men. Am J Public Health 1981;71:694-705.

12 Karasek RA, Russel RS, Theorell T. Physiology of stress and regeneration in job related cardiovascular illness. J Human Stress 1982;8:29-42.
13 Karasek RA, Triantis KP, Chaudhry SS. Coworker and supervisor support as moderators of associations between task characteristics and mental strain. Journal of Occupational Behaviour 1982;3:181-200.

14 Karasek RA, Theorell T, Schwartz JE, Schnall PL, Pieper CF, Michela JL. Job characteristics in relation to the prevalence of myocardial infarction in the US Health Examination Survey (HANES). Am J Public Health 1988;78:910-8.

15 LaCroix AZ, Haynes SG. Occupational exposure to high demand/low control work and coronary heart incidence in the Framingham cohort. Am J Epidemiol 1984;120:481.

16 LaCroix AZ, Haynes SG. Gender differences in the health effects of workplace roles. In: Barnett RC, Biener L, Baruch GK, eds. Gender and stress. London: The Free Press, 1987:96-121.

17 Pieper C, LaCroix AZ, Krasch RA. The relation of psychosocial dimensions of work with coronary heart disease risk factors. Am J Epidemiol 1989;129:483-95.

18 Reed DM, LaCroix AZ, Karasek RA, Miller DW, McLean CA. Occupational strain and the incidence of coronary heart disease. Am J Epidemiol 1989;129:495-502.

19 Schnall PL, Pieper C, Schwartz JE, et al. The relationship between 'job strain', workplace, diastolic blood pressure and left ventricular mass index. JAMA 1990;263:1929-35.

20 Theorell T, Hamsten A, de Faire U, Orth-Gomér K, Perski A. Psychosocial work conditions before myocardial infarction in young men. Int J Cardiol 1987;15:33-46.

21 Markowe HLJ, Marmot MG, Shipley MJ, et al. Fibrinogen: a possible link between social class and coronary heart disease. $B M J$ 1985;291:1312-4.

22 Kannel WB, Wolf PA, Castelli WP, D'Agostino RB. Fibrinogen and risk of cardiovascular disease. JAMA 1987;258:1 183-6.

23 Wilhelmsen L, Svärdsrudd K, Welin L, Tibblin G. Fibrinogen a risk factor for stroke and myocardial infarction. N Engl J Med 1984;311:501-5.

24 Meade TW, Vickers MV, Thompson SG. The effect of physiological levels on platelet aggregation. Thromb Res 1985;38:527-34.

25 Cesana G, Pariza G, Terrario M, Zanettini R, Arnoldi N, Grieco A. Can glycated hemoglobin be a job stress parameter? J Occup Med 1985;27:357-9.

26 Netterstrøm B, Danborg L, Olesen H. Glycated hemoglobin $\mathrm{HbA}, \mathrm{C}$ as a measure of physiological stress. Behavioural Medicine 1988;14:13-7.

27 Kwakami NS, Hyashi T, Masumoto T. Relationship between perceived job stress and glycosylated hemoglobin in whitecollar workers. Ind Health 1989;27:149-54.

28 WHO Monica Project, The World Health Organisation MONICA-project (Monitoring trends and determinants in cardiovascular diseases): A major international collaboration. Journal of Clinical Epidemiology 1988;41:105-14.

$29 \mathrm{Sjøl} \mathrm{A}$, Schroll M. Cardiovascular risk factor profile in Glostrup Community, MONICA-screening II, 1986/87. Ugeskr Lager 1990;152:3449-55. (In Danish with an English summary.)

30 Rose GA, Blackburn H. Cardiovascular survey methods. Geneva: World Health Organisation, 1968.

31 Chapman A, Mandryk JA, Frommer MS, Edye BV, Ferguson DA. Chronic perceived work stress and blood pressure among Australian government employees. Scand J Work Environ Health 1990;16:258-69.

32 Frommer MS, Edye BV, Mandryk JA, Grammeno GG, Berry G, Ferguson DA. Systolic blood pressure in relation to occupation and perceived work stress. Scand J Work Environ Health 1986;12:476-85.

33 Theorell T, Perski A, Ákerstedt T, et al. Changes in job strain in relation to changes in physiological state. A longitudinal study. Scand J Work Environ Health 1988;14:189-98.

34 Sterling P, Eyer J. Biological basis on stress related mortality. Soc Sci Med 1981;15E:3-42.

35 Mortensen HB. Glycated hemoglobin. Reaction and biokinetic studies, thesis. Copenhagen: Lægeforeningens Forlag, 1985.

Accepted 18 February 1991 